Jurnal Ilmu Ilmu Agribisnis: Journal of Agribusiness Science, 9(2), Mei 2021

\title{
KETAHANAN DAN KEMANDIRIAN PANGAN RUMAH TANGGA PETANI PADI DI DAERAH RAWAN PANGAN KECAMATAN PAGELARAN UTARA KABUPATEN PRINGSEWU
}

\author{
(Food security and food self-suffiency of paddy farmer households in food insecure area of North Pagelaran \\ Subdistrict of Pringsewu Regency)
}

Titis Widyawati Sholeha, Fembriarti Erry Prasmatiwi, Dyah Aring Hepiana Lestari

Jurusan Agribisnis, Fakultas Pertanian, Universitas Lampung, Jl. Prof. Dr. Soemantri Brojonegoro No.1

Bandar Lampung, 35141, e-mail: fembriarti.erry@fp.unila.ac.id

\begin{abstract}
The purposes of this research are to analyze the level of food security, the factors that affect the level of food security, and food self-suffiency of paddy households. North Pagelaran is chosen purposively as research location for the location is food insecure area. The respondents consist of fourty paddy household were selected by simple random sampling. The result of this research showed that the majority of household is classified as less food (47.50\%), as food secure (22.50\%) and the rest respondents classified as vulnerable food and food insecured (17.50\% and $12.50 \%$ ). The factors that affected the level of food security were the level formal education of housewives, paddy field, in addition to rice and egg price. Households food selfsuffiency in North Pagelaran distric has classified as high food self-suffiency.
\end{abstract}

Key words: Food insecure area, food security, food self-suffiency, paddy households

\section{PENDAHULUAN}

Sektor pertanian menjadi sektor unggulan di Kabupaten Pringsewu. Salah satu subsektor pertanian yang menonjol adalah tanaman pangan, khususnya padi. Berdasarkan Badan Pusat Statistik Provinsi Lampung (2018), Kabupaten Pringsewu memiliki luas lahan 29.072 ha atau sekitar 3,96 persen dari seluruh luas lahan sawah di Provinsi Lampung dengan produksi padi 156.541 ton atau sekitar 4,09 persen dari total produksi padi Provinsi Lampung.

Kecamatan Pagelaran Utara merupakan salah satu kecamatan hasil pemekaran dari Kecamatan Pagelaran dengan wilayah terluas yaitu sekitar 16,04 persen (Badan Pusat Statistik Kabupaten Pringsewu 2018). Namun, Kecamatan Pagelaran Utara menjadi wilayah penghasil padi terendah diantara kedelapan kecamatan lain di Kabupaten Pringsewu yaitu sebesar 3.101 ton.

Rendahnya produksi padi di Kecamatan Pagelaran Utara juga berimbas pada pendapatan yang akan diperoleh petani. Tingkat pendapatan yang relatif rendah dapat mengurangi kemampuan rumah tangga dalam memenuhi kebutuhan pangan, sehingga asupan pangan setiap anggota rumah tangga akan berkurang dan secara tidak langsung berpengaruh terhadap ketahanan pangan rumah tangga petani padi tersebut.
Undang-Undang Republik Indonesia Nomor 18 Tahun 2012 tentang Pangan mendefinisikan ketahanan pangan sebagai kondisi terpenuhinya pangan bagi negara sampai dengan perseorangan, yang tercermin dari tersedianya pangan yang cukup, baik jumlah maupun mutunya, aman, beragam, bergizi, merata, dan terjangkau serta tidak bertentangan dengan agama, keyakinan, dan budaya masyarakat, untuk dapat hidup sehat, aktif, dan produktif secara berkelanjutan.

Ruang lingkup ketahanan pangan mencakup tiga pilar utama yaitu ketersediaan, distribusi, dan konsumsi pangan. Pilar distribusi dan konsumsi merupakan penjabaran dari aksesibilitas masyarakat terhadap pangan. Apabila ketiga pilar tersebut tidak tercapai, maka ketahanan pangan tidak mungkin terbangun dan akibatnya menimbulkan daerah rawan pangan.

Berdasarkan Badan Ketahanan Pangan Kabupaten Pringsewu (2017), Kecamatan Pagelaran Utara termasuk sebagai wilayah rawan pangan. Rumah tangga petani padi selaku penyedia bahan pangan pokok bagi masyarakat memiliki dua peran, yaitu sebagai produsen dan juga sebagai konsumen. Petani sebagai produsen juga menentukan tingkat kemandirian pangan suatu wilayah.

Menurut Undang-Undang Republik Indonesia Nomor 18 Tahun 2012, kemandirian pangan adalah kemampuan negara dan bangsa dalam 
memproduksi pangan yang beraneka ragam dari dalam negeri yang dapat menjamin pemenuhan kebutuhan pangan yang cukup sampai tingkat perseorangan dengan memanfaatkan potensi sumberdaya alam, manusia, sosial, ekonomi, dan kearifan lokal secara bermartabat. Singkatnya, kemandirian pangan merupakan kemampuan petani dalam mencukupi kebutuhan konsumsi melalui produksi sendiri.

Wilayah yang mandiri pangan akan mewujudkan ketahanan pangan yang baik. Begitu pula dengan rumah tangga petani yang mampu mencukupi kebutuhan pangan melalui produksinya sendiri, maka ketahanan pangan pun akan baik. Kemandirian pangan menjadi isu yang penting mengingat besarnya potensi pertanian dan sumberdaya lokal untuk terus dikembangkan. Sebagai daerah yang menanam dan memproduksi padi, seyogyanya Kecamatan Pagelaran Utara memiliki ketahanan dan kemandirian pangan yang baik, namun kecamatan tersebut menjadi daerah rawan pangan. Karenanya, penanganan secara serius dan komprehensif dapat mengurangi terjadinya kerawanan pangan yang berkepanjangan.

Berdasarkan masalah tersebut, maka tujuan penelitian ini yaitu menganalisis tingkat ketahanan pangan, faktor-faktor yang memengaruhi ketahanan pangan, dan tingkat kemandirian pangan rumah tangga petani padi (RTPP) di daerah rawan pangan Kecamatan Pagelaran Utara Kabupaten Pringsewu.

\section{METODE PENELITIAN}

Metode penelitian yang digunakan dalam penelitian ini adalah metode survei. Penelitian ini dilaksanakan di Desa Kamilin dan di Desa Fajar Baru, Kecamatan Pagelaran Utara, Kabupaten Pringsewu. Lokasi penelitian dipilih secara sengaja (purposive) dengan pertimbangan bahwa kedua desa tersebut termasuk ke dalam kategori desa rawan pangan dan daerah penghasil padi di Kecamatan Pagelaran Utara. Metode pengambilan sampel menggunakan simple random sampling. Populasi dalam penelitian sebanyak 216 RTPP. Penentuan jumlah sampel mengacu pada Isaac dan Michael dalam Sugiarto, Siagian dan Sunaryanto (2003), sehingga diperoleh total sampel sebanyak 40 RTPP. Pengambilan sampel dilakukan secara proporsional dari dua desa, sehingga diperoleh jumlah sampel Desa Fajar Baru sebanyak 24 rumah tangga dan Desa Kamilin 16 rumah tangga petani.
Jenis data yang dikumpulkan adalah data primer dan sekunder. Data primer diperoleh dari responden melalui wawancara langsung dengan menggunakan alat bantu kuesioner. Data sekunder diperoleh dari instansi terkait dan literatur-literatur yang berhubungan dengan penelitian. Pengambilan data dilakukan pada bulan April - Mei 2019.

Tingkat ketahanan pangan rumah tangga diukur menggunakan klasifikasi silang antara pangsa pengeluaran dan tingkat kecukupan energi oleh Johnsson dan Toole dalam Maxwell, et al (2000) yang tersaji pada Tabel 1. Besarnya pangsa pengeluaran pangan didapat dari perbandingan antara besarnya pengeluaran pangan dengan total pengeluaran. Tingkat kecukupan energi diperoleh dengan membandingkan konsumsi aktual dan kecukupan yang dianjurkan LIPI (2012) dalam kegiatan Widyakarya Nasional Pangan dan Gizi (WKNPG) per kapita per hari menurut kelompok umur dan jenis kelamin.

Analisis faktor yang mempengaruhi ketahanan pangan menggunakan regresi ordinal logit dengan persamaan sebagai berikut :

$\mathrm{Pi}$

$$
\begin{aligned}
= & F(Z i) \\
= & F\left(\alpha+\beta_{1} X_{1}+\beta_{2} X_{2}+\beta_{3} X_{3}+\beta_{4} X_{4}+\beta_{5} X_{5}+\beta_{6}\right. \\
& \left.X_{6}+\beta_{7} X_{7}+\beta_{8} X_{8}+\beta_{9} X_{9}+e\right) \ldots \ldots \ldots \ldots \ldots \ldots \ldots . .
\end{aligned}
$$

Keterangan:

$\mathrm{Zi} \quad=$ Peluang $\mathrm{Z} 1=\mathrm{Z}(\mathrm{Y}=4)$ untuk rumah tangga petani tahan pangan Peluang $\mathrm{Z2}=\mathrm{Z}(\mathrm{Y}=3)$ untuk rumah tangga petani kurang pangan Peluang $\mathrm{Z3}=\mathrm{Z}(\mathrm{Y}=2)$ untuk rumah tangga petani rentan pangan Peluang $\mathrm{Z} 4=\mathrm{Z}(\mathrm{Y}=1)$ untuk rumah tangga petani rawan pangan

$\mathrm{Pi}=$ Peluang untuk menentukan tingkat ketahanan pangan bila Xi diketahui

$\alpha \quad=$ Intersep

$\beta_{\mathrm{i}} \quad=$ Koefisien variabel bebas $(\mathrm{i}=1-9)$

$\mathrm{X} 1=$ Jumlah anggota rumah tangga (orang)

X2 = Tingkat pendidikan ibu rumah tangga (tahun sukses)

$\mathrm{X} 3=$ Pendapatan rumah tangga $(\mathrm{Rp} / \mathrm{bln})$

$\mathrm{X} 4=$ Harga beras $(\mathrm{Rp} / \mathrm{kg})$

$\mathrm{X} 5=$ Harga minyak goreng $(\mathrm{Rp} / \mathrm{L})$

$\mathrm{X} 6=$ Harga gula $(\mathrm{Rp} / \mathrm{kg})$

$\mathrm{X} 7 \quad=$ Harga tempe $(\mathrm{Rp} /$ bungkus $)$

$\mathrm{X} 8=$ Harga telur $(\mathrm{Rp} / \mathrm{kg})$

$\mathrm{X} 9=$ Luas lahan (ha)

$\mathrm{e} \quad=$ Error term

TH $=\beta_{1}, \beta_{4}, \beta_{5}, \beta_{6}, \beta_{7}, \beta_{8}$, bertanda negatif dan $\beta_{2}, \beta_{3}, \beta_{9}$ bertanda positif 
Tabel 1. Kriteria derajat ketahanan pangan rumah tangga

\begin{tabular}{|c|c|c|}
\hline \multirow[b]{2}{*}{ Konsumsi energi } & \multicolumn{2}{|c|}{ Pangsa Pengeluaran Pangan } \\
\hline & Rendah $(<60 \%)$ & Tinggi $(>60 \%)$ \\
\hline $\begin{array}{l}\text { Cukup ( } \geq 80 \% \\
\text { kecukupan energi) }\end{array}$ & Tahan Pangan & Rentan Pangan \\
\hline $\begin{array}{l}\text { Kurang }(<80 \% \\
\text { kecukupan energi) }\end{array}$ & Kurang Pangan & Rawan Pangan \\
\hline
\end{tabular}

Uji Likelihood digunakan untuk mengetahui pengaruh semua variabel independen secara bersama-sama terhadap variabel dependen. Untuk menguji masing-masing variabel independen terhadap variabel dependen dapat dilakukan dengan melakukan Uji Wald dengan distribusi normal.

Kemandirian pangan dianalisis dengan mengacu pada penelitian Mulyo, Sugiyarto dan Widada (2015) dengan menggunakan Rasio Kecukupan (RK), dimana untuk menentukan tingkat kemandirian pangan menggunakan perbandingan antara produksi beras yang dihasilkan dan konsumsi beras. Menurut Baliwati dan Saputra (2014), jika RK <90 persen, maka termasuk tidak mandiri pangan (TMP). Tingkat kemandirian pangan diklasifikasikan menjadi tiga golongan yaitu: 1) tingkat kemandirian pangan rendah (MPR), jika 90>RK>110; 2) tingkat kemandirian pangan sedang (MPS), jika 111>RK>220 (surplus sampai dengan 100\%); 3) tingkat kemandirian pangan tinggi (MPT), jika RK $>220$ (surplus $>100 \%$ ).

\section{HASIL DAN PEMBAHASAN}

\section{Keadaan Umum Responden}

Secara keseluruhan, sebagian besar kepala RTPP berada pada rentang usia 51-63 tahun, sedangkan sebagian besar ibu RTPP berada pada rentang usia 38-50 tahun. Jenjang pendidikan formal yang ditempuh oleh kepala dan ibu RTPP sampai pada tingkat Sekolah Dasar (SD). Jumlah anggota rumah tangga yang dimiliki sebagian besar berkisar 2-4 orang. Pekerjaan pokok kepala rumah tangga adalah petani padi, namun 35 persen kepala RTPP memiliki pekerjaan sampingan sebagai buruh tani, pedagang, buruh bangunan, penyewa tarub dan meubel. Selain sebagai ibu rumah tangga, sebanyak 22,50 persen ibu rumah tangga memiliki pekerjaan sampingan antara lain sebagai petani, buruh tani, dan pedagang. Rumah tangga petani padi memiliki lahan pertanian berkisar $0,13-0,59$ ha.
Tabel 2. Struktur pendapatan rumah tangga petani padi di Kecamatan Pagelaran Utara

\begin{tabular}{llrr}
\hline No & Sumber pendapatan & $\begin{array}{c}\text { Pendapatan } \\
(\mathrm{Rp} / \mathrm{thn})\end{array}$ & $(\%)$ \\
\hline 1 & Usahatani padi & $5.622 .450,00$ & 26,50 \\
2 & Usahatani nonpadi & $742.525,00$ & 3,49 \\
3 & Usahatani tahunan & $4.870 .275,00$ & 22,95 \\
4 & Kegiatan nonusahatani & $3.010 .500,00$ & 14,19 \\
5 & Kegiatan nonpertanian & $4.734 .000,00$ & 22,31 \\
6 & Bantuan pemerintah & $2.237 .500,00$ & 10,55 \\
\hline & Jumlah & $21.217 .250,00$ & 100,00 \\
\hline
\end{tabular}

Penggunaan terbesar untuk usahatani padi yaitu sebesar 50,91 persen. Penggunaan lahan terendah $(6,88 \%)$ berupa ladang untuk usahatani jagung.

Kondisi lantai rumah responden berupa semen $(80,00 \%)$, keramik $(15,00 \%)$ dan lantai berupa tanah $(5,00 \%)$. Seluruh responden memiliki akses terhadap MCK. Akses air bersih setiap rumah tangga menggunakan sumur dan akses listrik menggunakan pulsa, sehingga penggunaan listrik dapat dikendalikan dengan mudah. Sebanyak 50 persen rumah tangga petani mendapatkan bantuan pemerintah berupa beras miskin (raskin), 37,50 persen rumah tangga mendapatkan bantuan dana dari Program Keluarga Harapan (PKH) dan sisanya 12,50 persen mendapatkan bantuan pemerintah berupa raskin dan $\mathrm{PKH}$.

Pendapatan RTPP diperoleh dari usahatani padi, usahatani nonpadi, usahatani tanaman tahunan, kegiatan nonusahatani, kegiatan nonpertanian dan bantuan pemerintah. Struktur pendapatan RTPP dapat dilihat pada Tabel 2. Merujuk Tabel 2 pendapatan rata-rata RTPP di Kecamatan Pagelaran Utara adalah Rp21.217.250,00/thn atau Rp1.768.104,17/bln.

Garis kemiskinan perkapita di daerah penelitian sebesar Rp450.472,40/kapita/bln, mengindikasikan bahwa pendapatan perkapita per bulan tersebut berada di atas garis kemiskinan menurut BPS Provinsi Lampung (2019) yaitu sebesar Rp418.309,00/kapita/bln.

\section{Ketahanan Pangan}

\section{Subsistem Ketersediaan}

Menurut Banita dan Harisudin (2013), besarnya ketersediaan pangan pokok diukur dengan cara menginventarisasi pangan pokok (beras) yang tersedia dalam keluarga baik yang diperoleh dari input yaitu produksi usahatani, pembelian dan pemberian yang dikurangi dengan output rumah 
tangga yaitu dijual, aktivitas sosial, dan diberikan kepada pihak lain. Merujuk pada Tabel 3, jumlah input ketersediaan pangan RTPP di Kecamatan Pagelaran Utara adalah 1.930,76 kg GKG/tahun. Mayoritas input ketersediaan pangan berasal dari produksi usahatani padi yaitu 96,66 persen.

Output pangan pokok di Kecamatan Pagelaran Utara adalah $1.010,73 \mathrm{~kg} \mathrm{GKG/tahun.} \mathrm{Mayoritas}$ output untuk dijual yaitu sebesar 96,46 persen dan sisanya diberikan kepada pihak lain sebesar 2,07 persen serta untuk aktivitas sosial. Ketersediaan pangan pokok rata-rata RTPP di Kecamatan Pagelaran Utara diperoleh dari nilai input dikurangi output adalah sebesar 49,08 $\mathrm{kg} / \mathrm{bulan} /$ rumah tangga atau setara dengan 1.529,87 $\mathrm{kkal} / \mathrm{kap} / \mathrm{hari}$.

Rata-rata beras yang dikonsumsi RTPP di Kecamatan Pagelaran Utara sebesar 318,90 gram/ kapita/hari atau setara dengan 1.148,05 kkal/ kapita/hari. Konsumsi beras tersebut menyumbang 53,40 persen dari standar konsumsi energi berdasarkan Angka Kecukupan Energi (AKE) berdasarkan hasil WNPG X sebesar 2.150 kkal/kapita/hari. Berdasarkan hasil kajian Badan Pusat Statistik (2015), konsumsi beras masyarakat Indonesia mencapai 312 gram per kapita per hari. Nilai tersebut menunjukkan bahwa rata-rata konsumsi beras RTPP di Kecamatan Pagelaran Utara tidak jauh berbeda dengan hasil kajian yang dilakukan oleh Badan Pusat Statistik.

Jika dilihat dari rata-rata ketersediaan pangan pokok beras dan rata-rata konsumsi beras oleh RTPP padi di Kecamatan Pagelaran Utara, maka RTPP di Kecamatan Pagelaran Utara mengalami surplus beras sebesar 106,06 gram/kapita/hari. Hal ini serupa dengan hasil penelitian Maryani, Prasmatiwi dan Adawiyah (2017) yang menyatakan bahwa RTPP anggota lumbung pangan di Kecamatan Ambarawa mengalami surplus beras sebesar 142,35 gram/kapita/hari.

\section{Subsistem Distribusi Pangan}

Subsistem distribusi pangan ditentukan oleh sarana dan prasarana yang ada pada setiap wilayah. Subsistem ini mencakup aksesibilitas fisik, ekonomi dan sosial. Akses pangan secara fisik ditunjukkan dengan kemampuan memproduksi pangan, kondisi infrastruktur dan sumber daya alam dan lingkungan pada wilayah tersebut (Delly, Prasmatiwi, dan Prayitno 2019).
Berdasarkan hasil penelitian, rumah tangga petani memiliki akses langsung terhadap bahan pangan pokok yaitu beras. Hal tersebut karena RTPP memiliki akses langsung berupa sawah yang menjadi tumpuan dalam berusahatani padi. Aksesibilitas secara sosial dilihat dari kebiasaan makan rumah tangga, dimana kebiasaan makan responden adalah tiga kali sehari dengan porsi yang cukup, dengan pangan pokok berupa beras. Namun, RTPP belum mengonsumsi makanan beragam dan bergizi seimbang. Aksesibilitas secara fisik juga dapat dilihat dengan adanya toko dan warung di daerah penelitian. Sarana dan prasarana khususnya infrastruktur dapat dikatakan belum memadai. Kondisi jalan yang rusak, berlubang, dan belum diaspal menjadi salah satu kendala bagi RTPP untuk beraktivitas.

Rumah tangga yang ingin berbelanja ke pasar harus rela ke pasar kecamatan, karena tidak ada pasar di desa. Jarak antara rumah petani responden dengan pasar rata-rata $3,26 \mathrm{~km}$. Jarak tersebut dapat dikatakan cukup jauh, sehingga rumah tangga petani lebih memilih membeli bahan pangan di warung dan toko daripada di pasar yang jaraknya cukup jauh.

\section{Subsistem Konsumsi}

Subsistem konsumsi menyangkut upaya peningkatan pengetahuan dan kemampuan masyarakat agar mempunyai pemahaman atas pangan, gizi, dan kesehatan yang baik sehingga dapat memilih bahan pangan yang beragam, bergizi seimbang dan aman. Rumah tangga petani padi mengonsumsi beras sebagai pangan pokok Pemenuhan protein bagi rumah tangga responden diperoleh dari mengkonsumsi lauk-pauk baik, hewani ataupun nabati. Lauk-pauk nabati yang mengandung protein seperti tahu dan tempe sering dikonsumsi oleh rumah tangga responden. Konsumsi tempe berkisar antara 8-9 kali, konsumsi tahu berkisar antara 5-6 kali dalam satu bulan.

Lauk-pauk lain yang mengandung protein yaitu lauk-pauk hewani seperti telur dan ikan segar. Telur menjadi makanan yang sering dihidangkan, bahkan bagi RTPP yang memiliki anak yang masih bersekolah. Sebanyak 26 RTPP menjadikan telur sebagai lauk pokok untuk dikonsumsi pagi hari untuk anak mereka. Rata-rata konsumsi telur dalam satu bulan sebesar $1,19 \mathrm{~kg}$. 
Jurnal Ilmu Ilmu Agribisnis: Journal of Agribusiness Science, 9(2), Mei 2021

Tabel. 3 Ketersediaan pangan pokok RTPP di Kecamatan Pagelaran Utara

\begin{tabular}{|c|c|c|c|c|c|c|}
\hline \multirow[t]{2}{*}{ Keterangan } & \multirow{2}{*}{$\begin{array}{l}\text { Gabah } \\
\text { Kg/thn }\end{array}$} & \multicolumn{3}{|c|}{ Beras } & \multirow{2}{*}{$\begin{array}{c}\text { Energi } \\
\text { Kkal/kap/hari }\end{array}$} & \multirow[t]{2}{*}{$\%$} \\
\hline & & $\mathrm{Kg} / \mathrm{thn}$ & $\mathrm{Kg} / \mathrm{bln}$ & g/kap/hari & & \\
\hline \multicolumn{7}{|l|}{ Input } \\
\hline Produksi & $1.866,25$ & $1.194,77$ & 99,56 & 862,03 & $3.103,31$ & 96,66 \\
\hline Pemberian & 0,00 & 0,00 & 0,00 & 0,00 & 0,00 & 0,00 \\
\hline Pembelian & 31,71 & 20,30 & 1,69 & 14,65 & 52,73 & 1,64 \\
\hline Raskin & 32,80 & 21,00 & 1,75 & 15,15 & 54,55 & 1,70 \\
\hline Jumlah (1) & $1.930,76$ & $1.236,07$ & 103,01 & 891,83 & $3.210,58$ & 100,00 \\
\hline \multicolumn{7}{|l|}{ Output } \\
\hline Dijual & 975,00 & 624,20 & 52,02 & 450,36 & $1.621,29$ & 96,46 \\
\hline Aktivitas sosial & 14,86 & 9,51 & 0,79 & 6,86 & 24,71 & 1,47 \\
\hline Diberikan pihak lain & 20,87 & 13,36 & 1,11 & 9,64 & 34,71 & 2,07 \\
\hline Jumlah (2) & $1.010,73$ & 647,07 & 53,92 & 466,86 & $1.680,71$ & 100,00 \\
\hline Ketersediaan (1-2) & 920,03 & 589,00 & 49,08 & 424,97 & $1.529,87$ & \\
\hline
\end{tabular}

Menurut Weol, et al (2014), rumah tangga di Kecamatan Suluun Tareran rata-rata mengonsumsi telur sebanyak $1,29 \mathrm{~kg} / \mathrm{bln}$. Ikan segar juga menjadi lauk-pauk pilihan sebagai menu pemenuhan protein antara lain ikan laut, ikan lele dan ikan gurame.

Pemenuhan serat bagi RTPP dilakukan dengan mengonsumsi sayuran dan buah. Sebanyak 62,50 persen menjawab sayuran yang paling sering dikonsumsi adalah daun singkong dan 12,50 persen mengatakan daun pepaya, dikarenakan sayuran tersebut mudah didapatkan di pekarangan ataupun kebun milik tetangga yang secara gratis dapat dikonsumsi. Buah yang sering dikonsumsi adalah salak, pepaya dan pisang.

Minyak goreng menjadi bahan pangan yang digunakan oleh seluruh RTPP. Penggunaan minyak goreng tidak dapat dilepaskan dari konsumsi sehari-hari dalam rumah tangga, terutama untuk menumis sayur atau menggoreng bahan pangan seperti pisang, tempe, tahu, ikan, dan telur. Rata-rata jumlah penggunaan minyak goreng $4 \mathrm{~L} / \mathrm{bln}$ setara dengan 1,01 L/kapita/bln.

Menurut Kementerian Pertanian (2017), penggunaan minyak goreng per rumah tangga tahun 2016 mencapai 0,97 L/kapita/bln. Gula merupakan salah satu bahan pangan penghasil energi dan digunakan sebagai pemanis baik untuk minuman ataupun masakan dan digunakan sebanyak $3 \mathrm{~kg} / \mathrm{bln}$. Penggunaan gula di rumah tangga pada tahun 2016 mencapai 0,62 $\mathrm{kg} / \mathrm{kapita} / \mathrm{bln}$. Hal ini tidak jauh berbeda dari hasil konsumsi gula di lokasi penelitian yaitu sebesar $0,76 \quad \mathrm{~kg} / \mathrm{kapita} / \mathrm{bln}$.

\section{Tingkat Ketahanan Pangan RTPP di Kecamatan Pagelaran Utara}

Merujuk pada Tabel 4, rata-rata pengeluaran pangan RTPP dalam satu bulan sebesar Rp1.002.100,76 atau 59,84 persen dari total pengeluaran rumah tangga, sedangkan rata-rata pengeluaran nonpangan rumah tangga sebesar Rp672.429,17 atau 40,16 persen dari total pengeluaran rumah tangga. Hal tersebut menunjukkan pengeluaran pangan mendominasi total pengeluaran rumah tangga petani. Pengeluaran pangan RTPP terbesar adalah untuk pangan beras sebesar 18,23 persen dan rokok yaitu 7,99 persen, sedangkan pengeluaran nonpangan terbesar digunakan untuk pendidikan $(12,59 \%)$ dan biaya bahan bakar $(11,01 \%)$.

Pangsa pengeluaran pangan dibedakan menjadi dua kriteria yaitu tinggi $(\geq 60 \%)$ dan rendah $(<60 \%)$. Sebanyak 70 persen RTPP memiliki pangsa pengeluaran pangan rendah. Pangsa pengeluaran yang rendah mengindikasikan pendapatan yang cukup tinggi, sehingga RTPP memiliki daya beli yang lebih tinggi untuk memenuhi kebutuhan pangan. Sebanyak 60 persen rumah tangga petani masih kekurangan energi yang mengindikasikan bahwa 60 persen RTPP belum mampu memilah bahan pangan yang sesuai dengan kebutuhan.

Sebaran pangsa pengeluaran pangan dan tingkat kecukupan energi RTPP tersaji pada Tabel 5 . Golongan padi-padian menyumbang 51,95 persen kontribusi terhadap Angka Kecukupan Energi (AKE). 
Tabel 4. Rata-rata total pengeluaran rumah tangga petani padi di Kecamatan Pagelaran Utara per bulan

\begin{tabular}{|c|c|c|c|}
\hline No & Jenis pengeluaran & Jumlah (Rp) & $(\%)$ \\
\hline \multirow{4}{*}{1} & Pangan & & \\
\hline & Pangan pokok & & \\
\hline & Beras & $305.075,00$ & 18,23 \\
\hline & Non beras & $33.275,00$ & 1,99 \\
\hline 2 & Lauk-pauk & $125.217,71$ & 7,48 \\
\hline 3 & Kacang-kacangan & $10.157,29$ & 0,61 \\
\hline 4 & Sayuran & $106.357,29$ & 6,36 \\
\hline 5 & Buah & $18.925,83$ & 1,13 \\
\hline 6 & Lemak & $45.204,17$ & 2,70 \\
\hline 7 & Minuman & $30.331,25$ & 1,81 \\
\hline 8 & Gula & $35.427,08$ & 2,12 \\
\hline 9 & Bumbu & $129.220,83$ & 7,72 \\
\hline 10 & Makanan jajanan & $29.134,30$ & 1,74 \\
\hline \multirow[t]{2}{*}{11} & Rokok & $133.775,00$ & 7,99 \\
\hline & $\begin{array}{l}\text { Total pengeluaran pangan } \\
\text { Non pangan }\end{array}$ & $1.002 .100,76$ & 59,84 \\
\hline 12 & Bahan bakar & $183.218,75$ & 11,01 \\
\hline 13 & Pendidikan & $210.839,93$ & 12,59 \\
\hline 14 & Kesehatan & $11.375,00$ & 0,68 \\
\hline 15 & Arisan & $38.375,00$ & 2,29 \\
\hline 16 & Rekreasi & 0,00 & 0,00 \\
\hline 17 & Transportasi & 0,00 & 0,00 \\
\hline 18 & Perbaikan rumah & $52.083,33$ & 3,11 \\
\hline 19 & Kebersihan badan & $44.050,00$ & 2,63 \\
\hline 20 & Kecantikan & $7.470,83$ & 0,45 \\
\hline 21 & Sosial & $4.541,67$ & 0,27 \\
\hline 22 & Pulsa & $77.983,33$ & 4,66 \\
\hline 23 & Pajak & $15.286,46$ & 0,91 \\
\hline 24 & Pakaian & $26.079,86$ & 1,56 \\
\hline \multirow[t]{3}{*}{25} & Perhiasan & 0,00 & 0,00 \\
\hline & $\begin{array}{l}\text { Total pengeluaran } \\
\text { nonpangan }\end{array}$ & $672.429,17$ & 40,16 \\
\hline & Total pengeluaran RT & $1.673 .529,93$ & 100,00 \\
\hline
\end{tabular}

Hal tersebut dikarenakan seluruh rumah tangga petani mengonsumsi nasi sebagai makanan pokok, sehingga memiliki ketergantungan yang besar terhadap beras. Hal ini tidak jauh berbeda dari penelitian Anggraini, Zakaria dan Prasmatiwi (2014) yang menyatakan konsumsi energi yang berasal dari pangan padi-padian rumah tangga petani kopi di Lampung Barat sebesar 56,46 persen.

Sebesar 8,75 persen dari total energi yang dikonsumsi oleh RTPP berasal dari minyak dan lemak, sebesar 6,93 persen berasal dari pangan hewani, sedangkan kontribusi pangan pangan terendah sebesar 0,25 persen berasal dari umbiumbian. Rata-rata konsumsi energi RTPP adalah 5.751,58 kkal/RTPP dengan TKE sebesar 73,58 persen. Hasil tersebut tidak jauh berbeda dari penelitian Delly, Prasmatiwi dan Prayitno (2019) yang menyatakan rata-rata konsumsi energi rumah tangga nelayan sebesar 7.911,32 kkal/rumah tangga dengan TKE sebesar 75,20 persen.
Tabel 5. Sebaran pangsa pengeluaran pangan dan tingkat kecukupan energi petani padi di Kecamatan Pagelaran Utara

\begin{tabular}{|c|c|c|c|}
\hline PPP & Kategori & Jumlah (n) & $(\%)$ \\
\hline$\geq 60 \%$ & Tinggi & 12 & 30,00 \\
\hline$<60 \%$ & Rendah & 28 & 70,00 \\
\hline \multicolumn{2}{|c|}{ Jumlah } & 40 & 100,00 \\
\hline TKE & Kategori & Jumlah (n) & $(\%)$ \\
\hline$\geq 80 \%$ & Cukup & 16 & 40,00 \\
\hline$\leq 80 \%$ & Kurang & 24 & 60,00 \\
\hline \multicolumn{2}{|c|}{ Jumlah } & 40 & 100,00 \\
\hline
\end{tabular}

Berdasarkan sembilan golongan pangan, kontribusi dari masing-masing golongan pangan terhadap rata-rata konsumsi per rumah tangga dapat dilihat pada Tabel 6.

Berdasarkan hasil klasifikasi silang antara pangsa pengeluaran pangan dan kecukupan energi, maka klasifikasi tingkat ketahanan pangan rumah tangga petani dapat dilihat pada Tabel 7. Mayoritas RTPP responden sebesar 47,50 persen tergolong dalam kategori kurang pangan dengan rata-rata TKE sebesar 71,60 persen dan PPP sebesar 54,81 persen.

Hal tersebut menunjukkan bahwa sebenarnya rumah tangga petani memiliki daya beli dan akses tinggi terhadap pangan, karena pangsa pengeluaran yang rendah dan mengindikasikan bahwa rumah tangga memiliki pendapatan yang cukup tinggi, akan tetapi kebutuhan energi rumah tangga petani belum tercukupi. Selain itu, sebanyak 22,50 persen RTPP berada pada kategori tahan pangan, sehingga meskipun menjadi daerah rawan pangan, masih terdapat RTPP di Kecamatan Pagelaran Utara yang

Tabel 6. Rata-rata konsumsi energi RTPP di Kecamatan Pagelaran Utara

\begin{tabular}{|c|c|c|c|c|}
\hline$\overline{\mathrm{No}}$ & $\begin{array}{c}\text { Golongan } \\
\text { pangan }\end{array}$ & $\begin{array}{c}\text { Rerata } \\
\text { konsumsi } \\
(\mathrm{kkal}) / \mathrm{rmh} \\
\text { tangga } \\
\end{array}$ & $\begin{array}{l}\text { Kontribusi } \\
\text { thdp total } \\
\text { konsumsi } \\
\quad(\%)\end{array}$ & $\begin{array}{l}\text { Kontribusi } \\
\text { thd AKE (\%) }\end{array}$ \\
\hline 1 & Padi-padian & $4.060,37$ & 70,37 & 51,95 \\
\hline 2 & Umbi-umbian & 14,25 & 0,25 & 0,18 \\
\hline 3 & Pangan hewani & 398,71 & 6,93 & 5,10 \\
\hline 4 & $\begin{array}{l}\text { Minyak dan } \\
\text { lemak }\end{array}$ & 503,02 & 8,75 & 6,44 \\
\hline 5 & $\begin{array}{l}\text { Buah-biji } \\
\text { berminyak }\end{array}$ & 56,11 & 0,98 & 0,72 \\
\hline 6 & $\begin{array}{l}\text { Kacang- } \\
\text { kacangan }\end{array}$ & 205,09 & 3,57 & 2,62 \\
\hline 7 & Gula & 91,89 & 1,60 & 1,18 \\
\hline 8 & Sayur dan buah & 90,38 & 1,57 & 1,16 \\
\hline 9 & Lain-lain & 331,57 & 5,77 & 4,24 \\
\hline \multicolumn{2}{|c|}{ Total } & $5.751,58$ & 100,00 & 73,58 \\
\hline \multicolumn{2}{|c|}{$\overline{\mathrm{TKE}}$} & $7.816,44$ & & \\
\hline
\end{tabular}


Jurnal Ilmu Ilmu Agribisnis: Journal of Agribusiness Science, 9(2), Mei 2021

Tabel 7. Sebaran rumah tangga berdasarkan tingkat ketahanan pangan

\begin{tabular}{|c|c|c|c|c|c|}
\hline No & $\begin{array}{c}\text { Ketahanan } \\
\text { Pangan }\end{array}$ & $\begin{array}{l}\text { PPP } \\
(\%)\end{array}$ & $\begin{array}{l}\text { TKE } \\
(\%)\end{array}$ & (n) & $(\%)$ \\
\hline 1 & Rawan pangan & 78,60 & 70,21 & 5 & 12,50 \\
\hline 2 & Rentan pangan & 74,96 & 83,98 & 7 & 17,50 \\
\hline 3 & Kurang pangan & 54,81 & 71,60 & 19 & 47,50 \\
\hline 4 & Tahan pangan & 55,02 & 85,35 & 9 & 22,50 \\
\hline & Jumlah & & & 40 & 100,00 \\
\hline
\end{tabular}

tergolong tahan pangan. Oleh karena itu, tingkat kerawanan pangan di daerah belum tentu mencerminkan kerawanan pangan pada rumah tangga.

\section{Faktor yang Mempengaruhi Ketahanan Pangan}

Berdasarkan Tabel 8, variabel yang berpengaruh positif terhadap tingkat ketahanan pangan adalah tingkat pendidikan ibu dan luas lahan, sedangkan faktor yang berpengaruh negatif terhadap ketahanan pangan adalah harga beras dan harga telur. Nilai Pseudo $\mathrm{R}^{2}$ sebesar 0,266 menjelaskan bahwa sebesar 26,60 persen variasi tingkat ketahanan pangan rumah tangga dapat dijelaskan oleh variasi variabel independen X1 sampai dengan X9. Nilai probability LR statistik sebesar 0,001 menjelaskan bahwa variabel jumlah anggota rumah tangga, tingkat pendidikan ibu rumah tangga, pendapatan rumah tangga, harga beras, harga minyak goreng, harga gula, harga tempe, harga telur dan luas lahan secara bersama-sama berpengaruh nyata terhadap tingkat ketahanan pangan RTPP.

Penelitian ini sejalan dengan hasil penelitian Delly, Prasmatiwi dan Prayitno (2019) yang menyatakan bahwa tingkat pendidikan ibu rumah tangga berpengaruh positif terhadap tingkat ketahanan pangan rumah tangga dan sejalan dengan penelitian Hernanda, Indriani dan Kalsum (2017) yang menyatakan bahwa luas lahan memiliki hubungan yang positif terhadap tingkat ketahanan pangan rumah tangga. Penelitian ini pun sejalan dengan penelitian Anggraini, Zakaria, dan Prasmatiwi (2014) yang menyatakan bahwa harga beras berpengaruh negatif terhadap ketahanan pangan rumah tangga.

\section{Kemandirian Pangan}

Produksi gabah kering giling RTPP di Kecamatan Pagelaran Utara sebesar $1.866,25 \mathrm{~kg} / \mathrm{thn}$, setara dengan 1.194,77 kg beras/thn (faktor konversi dari gabah kering giling menjadi beras sebesar $64,02 \%)$.
Tabel 8. Hasil regresi ordinal logit

\begin{tabular}{|c|c|c|c|}
\hline Variabel & $\mathrm{TH}$ & Coefficient & Prob. \\
\hline $\begin{array}{l}\text { Jumlah anggota } \\
\text { keluarga (X1) }\end{array}$ & $(-)$ & 0,492 & 0,113 \\
\hline $\begin{array}{l}\text { Tingkat pendidikan } \\
\text { IRT (X2) }\end{array}$ & $(+)$ & $0,556 * *$ & 0,014 \\
\hline $\begin{array}{l}\text { Pendapatan rumah } \\
\text { tangga (X3) }\end{array}$ & $(+)$ & 0,000 & 0,226 \\
\hline Harga beras (X4) & $(-)$ & $-0,001 *$ & 0,107 \\
\hline Harga minyak (X5) & $(-)$ & 0,000 & 0,132 \\
\hline Harga gula (X6) & $(-)$ & 0,000 & 0,523 \\
\hline Harga tempe (X7) & $(-)$ & 0,000 & 0,813 \\
\hline Harga telur (X8) & $(-)$ & $-0,000 * *$ & 0,017 \\
\hline Luas lahan (X9) & $(+)$ & $3,426^{*}$ & 0,072 \\
\hline Pseudo R-squared & & 0,266 & \\
\hline LR statistic & & 26,705 & \\
\hline Prob (LR statistic) & & 0,002 & \\
\hline \multicolumn{4}{|c|}{ Keterangan : } \\
\hline \multicolumn{4}{|c|}{$=$ Tanda Harapan } \\
\hline \multicolumn{4}{|c|}{$=$ Tingkat kepercayaan $90 \%$} \\
\hline \multicolumn{4}{|c|}{$=$ Tingkat kepercayaan $95 \%$} \\
\hline
\end{tabular}

Konsumsi beras RTPP sebesar 442,00 kg/thn. Kemandiran pangan beras RTPP di Kecamatan Pagelaran Utara mencapai angka 270,31 persen sehingga dikategorikan sebagai mandiri pangan tinggi. Penelitian ini sesuai dengan penelitian Mulyo, Sugiyarto, dan Widada (2015) yang menyatakan bahwa petani padi di Brojonegoro, Jawa Tengah juga mandiri pangan.

\section{KESIMPULAN}

Mayoritas RTPP di Kecamatan Pagelaran Utara tergolong dalam kategori kurang pangan $(47,50 \%)$, tahan pangan $(22,50 \%)$ dan sisanya tergolong rawan pangan dan rentan pangan $(12,50 \%$ dan $17,50 \%$ ). Pendidikan ibu rumah tangga dan luas lahan memiliki nilai koefisien yang positif, yang berarti setiap terjadi peningkatan terhadap pendidikan ibu rumah tangga dan luas lahan akan meningkatkan probabilitas rumah tangga untuk mencapai kondisi tahan pangan, sedangkan harga beras dan harga telur memiliki nilai koefisien yang negatif yang berarti setiap terjadi kenaikan harga beras dan harga telur akan menyebabkan penurunan probabilitas rumah tangga untuk mencapai kondisi tahan pangan. RTPP di Kecamatan Pagelaran Utara tergolong sebagai rumah tangga yang mandiri pangan tinggi.

\section{DAFTAR PUSTAKA}

Anggraini M, Zakaria WA, dan Prasmatiwi FE. 2014. Ketahanan pangan rumah tangga petani kopi di Kabupaten Lampung Barat. Jurnal Ilmu Ilmu Agribisnis, 2 (2): 124-132. http://jurnal.fp.unila. 
ac.id/index.php/JIA/article/view/737/678 Januari 2019].

Baliwati YF dan Saputra IM. 2014. Analisis kemandirian ikan dan pangan hewani lainnya pada 26 kabupaten/kota di Jawa Barat Tahun 2012. JPHPI, 17 (3): 186 - 196. https://repository.ipb.ac.id/bitstream/ handle/123456789/77492/JPHPI 2014_Vol.1 7_No.3_186196.pdf?sequence $=1 \&$ is Allowed =y [12 Mei 2019].

BKP [Badan Ketahanan Pangan] Kabupaten Pringsewu. 2017. Peta Ketahanan dan Kerentanan Pangan Kabupaten Pringsewu Tahun 2017. BKP Kabupaten Pringsewu. Pringsewu.

BPS [Badan Pusat Statistik]. 2015. Konsumsi RataRata per Kapita Seminggu Beberapa Macam Bahan Makanan Penting, 2007-2015. BPS. Jakarta.

BPS [Badan Pusat Statistik] Kabupaten Pringsewu. 2018. Pringsewu dalam Angka. BPS Kabupaten Pringsewu. Pringsewu.

BPS [Badan Pusat Statistik] Provinsi Lampung. 2018. Data Luas Lahan, Produksi, dan Produktivitas Padi Sawah Menurut Kabupaten/Kota Provinsi Lampung Tahun 2017. BPS Provinsi Lampung. Bandar Lampung.

BPS [Badan Pusat Statistik] Provinsi Lampung. 2019. Profil Kemiskinan Maret 2019. BPS Provinsi Lampung. Bandar Lampung.

Banita D dan Harisudin M. 2013. Analisis ketersediaan pangan pokok dan pola konsumsi rumah tangga petani di Kabupaten Wonogiri. Jurnal SEPA, 1(01): 112-122. http://agribisnis.fp.uns.ac.id/wpcontent/JURN AL-DIAN-BANITA-H1310001.pdf. [25 Juli 2019].

Delly DP, Prasmatiwi FE, dan Prayitno RT. 2019. Ketahanan pangan rumah tangga nelayan di Desa Sukajaya Lempasing Kecamatan Teluk Pandan Kabupaten Pesawaran. Jurnal Ilmu Ilmu Agribisnis, 7 (2): 141-148. http://jurnal.fp.unila.ac.id/index. php/JIA/article/download/3373/2575 September 2019].

Hernanda ENP, Indriani Y dan Kalsum U. 2017. Pendapatan dan ketahanan pangan rumah tangga petani padi di Desa Rawan Pangan. Jurnal Ilmu Ilmu Agribisnis, 5 (3): 283-291. http://jurnal.fp.unila. ac.id/index.php/JIA/article/view/1641/1467 [04 Januari 2019].

Kementerian Pertanian. 2017. Buletin Konsumsi Pangan. E-Publikasi Kementan. Jakarta.

LIPI [Lembaga Ilmu Pengetahuan Indonesia]. 2012. Widyakarya Nasional Pangan dan Gizi (WNPG) X tahun 2012. Prosiding. LIPI. Jakarta.

Maryani S, Prasmatiwi FE dan Adawiyah R. 2017. Ketersediaan pangan dan faktor-faktor yang mempengaruhi ketersediaan pangan RT petani padi anggota lumbung pangan di Kecamatan Ambarawa Kabupaten Pringsewu. Jurnal Ilmu Ilmu Agribisnis, 5 (3): 304-311. http:// jurnal.fp.unila.ac.id/index.php/JIA/article/dow nload/1643/1469 [19 Juli 2019].

Maxwell DC, Levin MA, Klemeseau, M Rull, S Morris and C Aliadeke. 2000. Urban Livelihoods and Food Nutrition Security in Greater Accra, Ghana. IFPRI in Collaborative with Noguchi Memorial for Medical Researce and WHO, Researce Report No.112. Washington, D.C.

Mulyo JH, Sugiyarto dan Widada AW. 2015. Ketahanan dan kemandirian pangan RTPP di daerah marginal di Kabupaten Bojonegoro. Agro Ekonomi, 26 (2): 121-128. https://jurnal.ugm.ac.id/jae/article/viewFile/17 265/11256\&sa=U\&ved=2ahUKEwjky82shqP gAhWEWysKHVrDB74QFjAAegQIBxAB\& usg=AOvVaw16G_FmZbgIP62RZ19A3wj0 [28 Desember 2018].

Sugiarto D, Siagian LT dan Sunaryanto. 2003. Teknik Sampling. PT Gramedia Pustaka Utama. Jakarta.

Yuliana P, Zakaria WA dan Adawiyah R. 2013. Ketahanan pangan rumah tangga nelayan di Kecamatan Teluk Betung Selatan Kota Bandar Lampung. Jurnal Ilmu Ilmu Agribisnis, 11 (2): 181-186. http://jurnal.fp.unila.ac.id/index.php/JIA /article/view/246/245 [11 Januari 2019].

Weol EF, Rorimpandey B, Lenzum D, Endoh M. 2014. Analisis pengaruh pendapatan rumah tangga terhadap konsumsi daging dan telur di Kecamatan Suluun Tareran Kabupaten Minahasa Selatan. Jurnal Zootek, 34 (1): 3747. https://ejournal.unsrat.ac.id/index. php/zootek/article/viewFile/3870/3383 [20 November 2019]. 